\title{
On the Origin of Hyperglyeaemia in the Obese-Hyperglycaemic Mouse (obob): Effect of Diet on Blood Glucose and Serum Insulin in obob and Gold-Thioglucose Obese Mice
}

\author{
C. Chlouverakis
}

\author{
Department of Medicine, State University of New York at Buffalo and E.J. Meyer Mernorial Hospital, Buffalo, \\ New York, USA
}

Received: March 25, 1971, accepted: July 27, 1971

Summary. Obese-hyperglycaemic mice (obob), goldthioglucose obese (GTG-obese) and normal control mice were fed a high-carbohydrate and a carbohydrate-free diet. Blood glucose and serum insulin levels were influenced by the diet in all animals studied, but more so in the $o b o b$ and GTG-obese. Blood glucose levels were equally raised in both types of obesity. Serum insulin of GTG-obese showed a marked elevation above normal but failed to reach the serum insulin levels of the obob. The blood glucose of $o b o b$ and lean controls remained constant when fed the carbohydrate-free diet. Under these conditions, a trace amount of $\mathrm{U}^{14} \mathrm{C}$-glucose was injected intravenously. The rate of ${ }^{14} \mathrm{C}$-glucose disappearance from the blood followed first-order kinetics and did not differ between $a b o b$ and lean mice, suggesting a similar fractional rate of glucose uptake by tissues. The presence of a normal fractional rate of glucose extraction by the tissues of $o b o b$, together with their hyperglycaemia and a normal volume of glucose distribution suggests an increased absolute rate of tissue glucose uptake. This increase is likely to be due to the expanded mass of adipose tissue in these animals.

L'origine de l'hyperglycémie chez la souris obèse-hyperglycémique (obob): Hfffet du régime sur le niveau de la glycémie et de l'insuline du sérum chez obob et chez la souris rendue obèse par aurothioglucose

Résumé. Un régime riche ou dépourvu d'hydrates de carbone a été donné à un groupe de souris obèse-hyper. glycémique (obob), à un deuxième groupe de souris rendues obèses par aurothioglucose (GTG-obèse) et à un groupe de témoins. La glycémie et l'insulinémie ont été modifiées par le régime chez tous les animaux et particulièrement chez les obob et $G T G$-obèses. Le niveau de la glycémie était élevé do façon égale chez les deux groupes do souris obèses. L'insulinémie des souris GTG-obèses était considérablement augmentée mais n'atteignait pas le niveau de l'insulinémie observée chez les obob. Lo taux de glycómie des obob et des témoins est demeuré constant quand les animaux recevaient le régime dépourvu d'hydrates de carbone. A ce stade, nous avons injecté par voio intraveineuse une quantité traceuse de U. ${ }^{14} \mathrm{C}$-glucose. La vitesse de disparition du traceur obéissait à une cinétique d'ordre un et était semblable chez les obob et les témoins, suggérant ainsi que I'utilisation fractionnelle du glucose était semblable chez les deux groupes. L'existence d'une utilisation fractionelle normale du glucose chez les obob jointe à l'hyperglycémie et à un volume normal de distribution du glucose suggère que l'utilisation absolue du glucose chez ces animaux est augmentée. Cette augmentation est vraisemblablement due à l'expansion du tissu adipeux chez les obob.

Über die Ursache der Hyperglykämie bei der fettsüchtig. hyperglykämischen Maus (obob): Einwirkung der Diät auf die Blutglucose und das Serum Insulin bei obob und fettsüchtigem Goldthioglucosemäusen

Zusammenfassung. Fettsüchtig-hyperglykämische (obob), fettsüchtige Goldthioglucose- (GTG-obese) und normale Kontrollmäuse erhielten einmal eine Diät mit hohem Kohlenhydratgehalt und zum anderen eine kohlen. hydratfreie Diät. Bei allen Tieren wurde die Blutglucose und der Blutinsulinspiegel durch die Diät beeinflußt, am meisten aber bei den obob und GTG-obese Mäusen. Der Blutzuckerspiegel erhöhte sich bei beiden Fettsuchtstypen in gleichem Maße. Die Insulinspiegel der GTGMäuse waren erhöht, erreichten aber nicht die Werte der obob-Mäuse. Während der Verabreichung der kohlenhydratfreien Diät blieben die Blutzuckerspiegel der obobund der Kontrollmäuse konstant. Unter diesen Versuchs bedingungen wurde eine Spürdosis von ${ }^{14} \mathrm{C}$-Glucose i.v. injiziert. Die Abbaurate der Blut- ${ }^{14} \mathrm{C}$-Glucose folgte einer Kinetik erster Ordnung und wies keinen Unterschied zwischen obob- und Kontrollmäusen auf, was auf eine ähnliche fraktionierte Aufnahmerate der Glucose durch das Gewebe schließen läßt. Das Vorhandensein einer normalen fraktionierten Rate der Glucoseextraktion durch die Gewebe bei obob-Mäusen läßt im Zusammenhang mit der Hyperglykämie und einem normalen Verteilungsvolumen für Glucose eine erhöhte absolute Rate der Glucoseaufnahme durch die Gewebe vermuten. Die Erhöhung ist wahrscheinlich auf die große Fettmasse dieser Tiere zurückzuführen.

Key-words: $o b o b$ mice, gold-thioglucose obese mice, dietary, carbohydrate, hyperglycaemia, serum insulin, insulin resistance, glucose disappearance.
It is still unclear to what extent excessive food intake contributes to the hyperglycaemia of the obesehyperglycaemic mouse (obob). Thus, the blood glucose returns to normal when $o b o b$ are fasted even for a few hours [12]. Furthermore, although obese-hyperglycaemic mice (obob) show a normal response to small amounts of oral glucose, the response is abnormal if they are given an amount of glucose proportional to their body weight [2].

Fvidence against excessive food intake being solely responsible for the hyperglycaemia has been provided mainly by Mayer, who reported that mice rendered 
obese by injection of gold-thioglucose, except for very old and obese animals, are normo-glycaemic despite an excessive food intake [13]. In addition, an increased rate of endogenous synthesis of glucose and activity of gluconeogenio enzymes has been reported in the $a b o b$ $[15,16,9]$. It is therefore conceivable that the hyperglycaemia of the $o b o b$ might result from an increased endogenous synthesis of glucose.

These two factors, i.e. excessive dietary intake of carbohydrates and endogenous production of glucose (via gluconeogenesis), were evaluated in the present study.

\section{Materials and Methods}

Animals: The animals used in this study were purchased from the Jackson Memorial Laboratory (Bar Harbor, Maine) and consisted of male obese- hyperglycaemie mice (obob) and their lean littermates. All animals were brought into the laboratory at the age of 4 to 5 weeks and a week later a number of lean animals were injected intraperitoneally with a solution of gold-thioglucose ${ }^{1}$ in water $(60 \mathrm{mg} / \mathrm{ml}, 0.6 \mathrm{mg}$ goldthioglucose injected per $g$ body weight). The actual experimental study began when all animals were 4 months of age. Fourteen obese-hyperglycaemic mice 14 lean littermates and 14 gold-thioglucose obese mice (GTG-obese) were subjected to a dietary experiment which is described below.

I. Dietary experiment. This experiment lasted 30 days and was divided into four periods, two control and two experimental, as follows.

1 st control period (1 st to 5 th day):

All animals were fed a pellet mouse/rat diet (Teklad Inc., Monmouth, Ill.).

\section{1st experimental period (6th to 15 th day):}

Lean, $o b o b$ and gold-thioglucose obese mice (GTGobese) were separated into two dietary groups. One group was fed a high-carbohydrate diet and the other a carbohydrate-free diet (Nutritional Biochemicals Corp., Cleveland, Ohio). There were thus six groups of animals (each consisting of seven mice) three of which were fed the high-carbohydrate and the other three the carbohydrate-free diet, both in powder form.

2 nd control period (16 th to 20th day): As in the first control period all animals were fed the pellet mouse/rat diet.

2 nd experimental period (21 st to 30th day): During this period the groups of the first experimental period were reversed and animals that had taken the highcarbohydrate diet were now fed the carbohydrate-free diet and vice-versa. Thus, each animal served as its own control for either of the two experimental diets.

1 Generously donated by Dr. Tabachnick, Ph. D., Schering Corp., Bloomfield, N.J.
The composition of the three diets is shown in Table 1. The carbohydrate content of the high-carbohydrate diet was less than that of the pellet mouse/rat diet $(47.0$ v. $55.7 \%$ ). Food intake was measured daily and the average food intake was derived for individual mice during each control and experimental period. Animals were weighed on the first and last day of the four dietary periods and body weight changes during these periods were determined.

Glucose and insulin were determined on whole

Table 1. Diet composition (by weight)

\begin{tabular}{lccc}
\hline & Pellet & $\begin{array}{l}\text { High } \\
\text { Carbohydrate }\end{array}$ & $\begin{array}{c}\text { Carbohydrate- } \\
\text { free }\end{array}$ \\
\hline \% carbohydrate & 55.7 & 47.0 & 0.0 \\
$\%$ protein & 24.7 & 20.0 & 36.0 \\
$\%$ fat & 6.5 & 6.0 & 20.0 \\
$\%$ minerals & $\mathbf{6 . 1}$ & 4.0 & 4.0 \\
\% fibre & $\mathbf{3 . 3}$ & $\mathbf{2 3 . 0}$ & 40.0 \\
cal/g & $\mathbf{3 . 4 4}$ & $\mathbf{3 . 2 2}$ & $\mathbf{3 . 2 2}$ \\
\hline
\end{tabular}

blood and serum respectively. Blood was withdrawn from the ophthalmio venous plexus under light ether anaesthesia. Glucose was estimated on the last day of each control period and on the middle and last day of each experimental period on $20 \mu / \mathrm{blood}$, using a commercially available method (Glucostat, Worthington, Biochem. Corp., Freehold, N.J.). The two blood glucose values of each experimental period were pooled for each animal.

Serum immunoreactive insulin (IRI) was determined on the last day of each period using a previously published adaptation [2] of the double-antibody immunoassay of Hales and Randle [7].

II. Rate of glucose disappearance from the circulation in obob and lean control mice fed a carbohydrate-free diet. To test the variability of blood glucose in obob and lean mice an experiment was performed in which 12 male $o b o b$, four months old, and an equal number of lean control mice were divided into three groups. One of these groups was fed ad libitum the pellet mouse/rat diet (vide supra) before and during the experiment. The second group was fed a similar diet but was fasted the night before and also during the experiment. The third group had free access to the oarbohydrate-free diet for a period of four days before and during the experiment. $20 \mu /$ blood was withdrawn from animals for blood glucose estimation five times in the course of $6 \frac{1}{2} \mathrm{~h}$, the first blood sample having been obtained at 9:00 a.m. No glycosuria was present in any of the animals fasted overnight or fed the carbohydrate-free diet. In this experiment it was found (see Results) that while on a carbohydrate-free diet blood glucose showed little variation and, therefore, in the absence of exogenous carbohydrates, the rate of glucose disappearance from the circulation was equal to that 
of endogenously produced glucose entering the blood stream. A tracer amount of radioactive glucose was injected intravenously into obese-hyperglycaemic and lean control mice under these conditions of constancy of blood glucose, and the rate of disappearance of ${ }^{1.4} \mathrm{C}$ glucose was measured.

The experiment involving determination of the rate of $\mathrm{U}^{14} \mathrm{C}$-glucose from the circulation of obesehyperglycaemic mice (obob) and their lean littermates was performed as follows:

\section{Results}

The order in which the two experimental diets were fed had no effect on the variables measured, i.e. mean food intake, body weight, blood glucose and serum insulin levels. Similarly, these variables did not differ between the two control periods. Accordingly, the data were pooled for animals in each of the three groups (i.e. lean, $o b o b$ and gold-thioglucose obese mice) on the same diet.

Table 2. Food intake, body weight, blood glucose and serum insulin (mean $\pm S E M$ ) in lean, obob and GTG-obese mice, fed a standard pellet, a high-carbohydrate and a carbohydrate-free diet. Numbers in parentheses show numbers of observations

\begin{tabular}{|c|c|c|c|c|c|c|c|c|c|}
\hline & lean & & & $a b o b$ & & & GTG-obese & & \\
\hline & Pellet & High CHO & No CHO & Pellet & High CHO & No $\mathrm{CHO}$ & Pellet & High CHO & No $\mathrm{CHO}$ \\
\hline $\begin{array}{l}\text { Food } \\
\text { intake } \\
(\mathrm{g} / \text { day })\end{array}$ & & $\begin{array}{c}5.0 \pm 0.1 \\
(14)\end{array}$ & $\begin{array}{c}3.9 \pm 0.1 \\
(14)\end{array}$ & & $\frac{5.6 \pm 0.3}{(\mathbf{1 4})}$ & $\frac{4.5+0.1}{(14)}$ & & $\begin{array}{c}5.3 \pm 0.2 \\
(14)\end{array}$ & $\frac{4.8+0.3}{(14)}$ \\
\hline $\begin{array}{l}\text { Body } \\
\text { weight } \\
\text { (g) }\end{array}$ & $\begin{array}{c}28.9 \pm 0.6 \\
(28)\end{array}$ & $29.8 \pm 0.6$ & $\begin{array}{c}28.2+0.5 \\
(14)\end{array}$ & $\begin{array}{c}58.9 \pm 1.0 \\
(28)\end{array}$ & $\begin{array}{c}57.6 \pm 0.7 \\
(14)\end{array}$ & $\underset{(14)}{58.8+1.2}$ & $\begin{array}{c}44.9 \pm 1.0 \\
(28)\end{array}$ & $\begin{array}{c}44.6 \pm 0.8 \\
(14)\end{array}$ & $\begin{array}{c}45.0 \pm 0.9 \\
(\mathbf{1 4})\end{array}$ \\
\hline $\begin{array}{l}\text { Blood } \\
\text { glucose } \\
(\mathrm{mg} / 100 \mathrm{ml})\end{array}$ & $\begin{array}{c}144.2 \pm 3.7 \\
(28)\end{array}$ & $\begin{array}{c}132.5 \pm 4.3 \\
(14)\end{array}$ & $\begin{array}{c}121.6 \pm 2.5 \\
(14)\end{array}$ & ) $178.8 \pm 6.6$ & $\begin{array}{c}163.6 \pm 7.9 \\
(14)\end{array}$ & $\begin{array}{c}149.7 \pm 9.2 \\
(14)\end{array}$ & $\begin{array}{c}176.2 \frac{1}{\frac{1}{2}} 5.6 \\
(28)\end{array}$ & $\begin{array}{c}179.7 \pm 10.0 \\
(14)\end{array}$ & $\underset{(14)}{153.6+5.4}$ \\
\hline $\begin{array}{l}\text { Serum } \\
\text { Insulin } \\
(\mu \mathrm{U} / \mathrm{ml})\end{array}$ & $\begin{array}{c}43 \pm 5 \\
(28)\end{array}$ & $\begin{array}{c}56 \pm 12 \\
(14)\end{array}$ & $\begin{array}{c}33 \pm 7 \\
(14)\end{array}$ & $\begin{array}{c}1515 \doteq 166 \\
(28)\end{array}$ & $\begin{array}{c}1600 \pm 320 \\
(14)\end{array}$ & $\begin{array}{c}732 \pm 144 \\
(14)\end{array}$ & $\begin{array}{c}473 \pm 77 \\
(28)\end{array}$ & $\begin{array}{l}464 \pm 124 \\
(14)\end{array}$ & $\begin{array}{c}139 \pm 49 \\
(14)\end{array}$ \\
\hline
\end{tabular}

Eight male obese-hyperglycaemic mice (obob) four months of age and an equal number of lean control mice, were fed the carbohydrate-free diet for a period of four days, at the end of which a fixed volume $(0.2 \mathrm{ml})$ of a trace amount of $\mathrm{U}^{14} \mathrm{C}$-glucose in saline $(5 \mu \mathrm{a} / \mathrm{ml}$, spec. activity $0.3 \mathrm{mcj} / \mathrm{mM}$, the Radiochemical Centre, Amersham, England) was injected rapidly into the tail vein. Thus, each mouse received approximately 1 ua of radioactivity and $60 \mu \mathrm{g}$ glucose. At 5, 10, 15, 20 and. $30 \mathrm{~min}$ following the injection, $20 \mu /$ blood was taken from each animal for determination of blood glucose radioactivity. ${ }^{14} \mathrm{C}$-glucose in the blood was determined by an adaptation of the method of Delisle and Fritz [6] as follows: the blood was deproteinized with $3 \mathrm{ml}$ of $\mathrm{ZnSO}_{4} / \mathrm{Ba}(\mathrm{OH})_{2}$ and an aliquot $(1.5 \mathrm{ml})$ of the filtrate was mixed with $0.5 \mathrm{~g}$ of a mixed bed resin ( $\mathrm{AG}$ 501-X8, 20-50 Mesh, Bio Rad Laboratories, Richmond, Cal.), pre-equilibrated with $0.5 \mathrm{ml}$ of a glucose solution, $250 \mathrm{mg} / \mathrm{ml}$. The mixture was incubated for $90 \mathrm{~min}$ at $37^{\circ} \mathrm{C}$ in a shaking metabolic incubator. After centrifugation, $1 \mathrm{ml}$ of the clear supernatant was pipetted into $10 \mathrm{ml}$ of Bray's scintillator [1] and counted in a Nuclear-Chicago Liquid scintillation spectrometer using channel's ratio to correct for quenching. The data of dpm versus time were subjected to covariance analysis after logarithmic transformation of $\mathrm{dpm}$, and the best fitting straight regression line was calculated separately for $a b o b$ and lean mice [17].
A summary of these pooled data is shown in Table 2. While on the high-carbohydrate diet the daily food consumption was approximately the same for the three groups of animals. Lean mice, however, consumed significantly less quantities of the carbohydrate-free diet than the two obese groups $(p<0.001)$. Obese-hyperglycaemic and gold-thioglucose obese mice consumed similar quantities of either experimental diet. The lower caloric intake of lean animals on the carbohydrate-free diet was accompanied by a small but significant decrease in body weight compared with their weight on the high-carbohydrate diet $(p<0.01)$. There was no other, statistically significant, diet-effect on the animal's body weight.

This relative lack of effect of carbohydrate content of the diet on the animal's body weight was in contrast to its marked effect on the blood glucose and serum insulin levels. Thus, the carbohydrate-free diet caused a significant decrease of the blood glucose and serum insulin in all three groups of animals. The blood glucose and serum insulin levels of the lean animals were significantly lower than those of either groups of obese mice. In addition, blood glucose level was almost identical in $o b o b$ and gold-thioglucose obese mice fed the same diet, but serum insulin was significantly higher in the former (Table 2).

The variation of blood glucose with time in the three dietary groups of lean mice was small. Similarly, blood 
glucose changed little in obob fed the carbohydrate-free diet or fasted overnight, but showed marked variation in $o b o b$ fed the standard pellet diet (Fig. 1). The mean standard deviation derived from the standard deviations of

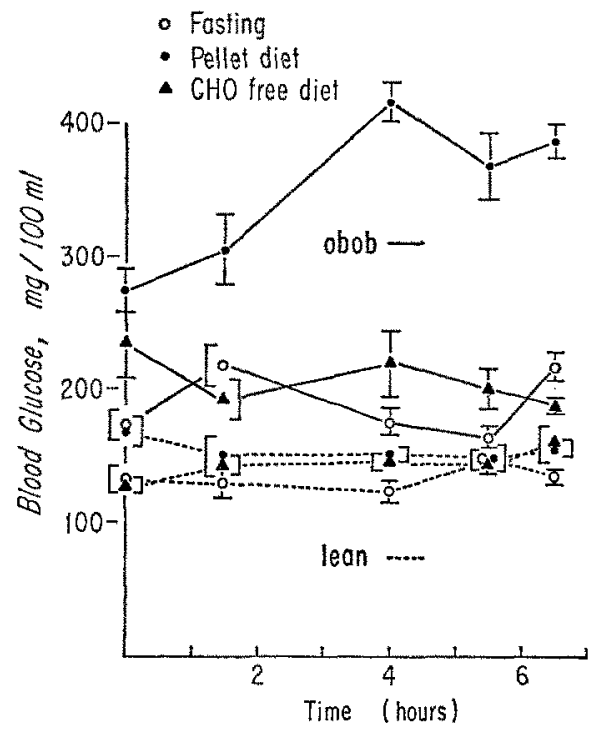

Fig. 1. Variability of blood glucose concentration in $o b o b$ and lean control mice, fed a standard pellet diet, a carbohydrate-free diet, or following an overnight fast. Each point is the mean of four animals. Vertical lines indicate standard error of mean.

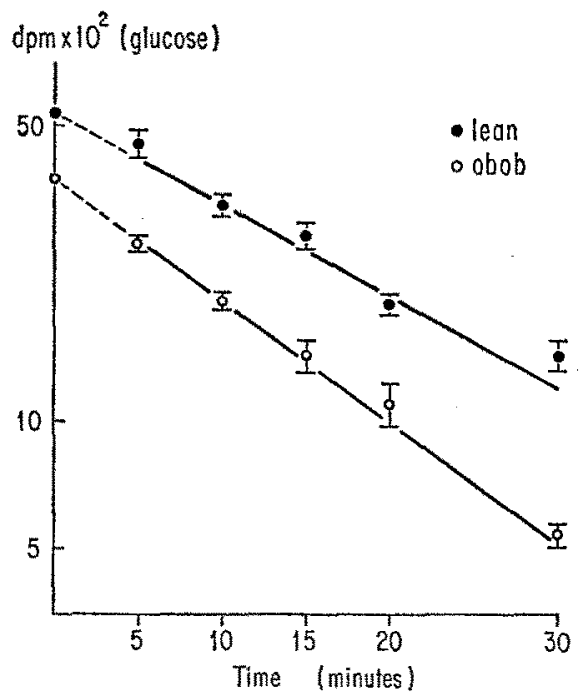

Fig. 2. Disappearance rate of a trace amount of U. ${ }^{14} \mathrm{C}$ glucose injected intravenously into obob and lean control mice. Each point is the mean of eight animals. Vertical lines indicate standard error of mean.

the mean blood glucose of each mouse was greatest in mice fed the pellet diet, but did not differ significantly between mice fed the carbohydrate-free diet or fasted overnight $(p>0.05)$. This was true for both obob and lean mice. While on a carbohydrate-free diet the dis- appearance of a trace amount of ${ }^{14} \mathrm{C}$-glucose from the circulation of both obese and lean mice approached first-order kinetics, and the F-ratio for non-parallelism of the two regression. lines [17] failed to achieve statistical significance $(p=0.2)$. These data suggest that the apparent rate of glucose disappearance from the circulation is proportional to its concentration, and that the proportionality constant is the same in lean and obese-hyperglycaemic mice (Fig. 2).

\section{Discussion}

The present data fail to support the contention made by Mayer that hyperglycaemia characterizes mice with metabolic obesity and is not encountered in animals with regulatory obesity [13]. In the present experiments, obese-hyperglycaemic and gold-thioglucose obese mice had similar blood glucose levels, regardless of nutritional status. Serum insulin was raised in both $a b o b$ and GTG-obese mice and was markedly decreased on feeding the carbohydrate-free diet. The raised serum insulin levels of the GTG-obese mice in association with their hyperglycaemia implies the presence of insulin resistance. These data, then, are in basic agreement with earlier reports indicating increased levels of both glucose and insulin in mice with gold-thioglucose-induced obesity $[10,5]$, and also with reports suggesting the presence of insulin resistance in adult rats with electrolytic lesions in the rentromedial nucleus of the hypothalamus $[11,8]$. The blood glucose levels were similar in obob and GTGobese mice despite much higher insulin levels in the former suggesting a greater degree of insulin resistance in the $a b o b$ compared with GTG-obese mice. This, however, should be expected if, as suggested by previous studies, insulin resistance is secondary to obesity [3]. The obese-hyperglycaemic mice used in the present studies were considerably heavier than the GTG-obese mice and the average value of their carcass fat was $39.5 \mathrm{~g}$ compared with 25.3 in the gold-thioglucose obese mice [4].

The present data also indicate that the nutritional status influences blood glucose more in obese-hyperglycaemic than in lean mice. Thus, obob respond to an overnight fast and to a carhohydrate-free diet by a marked decrease of blood glucose. Despite this decrease, however, the blood glucose level of the obob is still higher than that of the lean littermates. These findings are in basic agreement with previous reports showing an increased sensitivity of the blood glucose of the $o b o b$ to fasting [12]. In this context, an overnight fast and feeding a carbohydrate-free diet are basically similar in their effects on body glucose homeostasis, in that blood glucose is derived from endogenous synthesis in both. It is of interest, therefore, that there was no significant difference in the blood glucose of the $o b o b$ mice fasted overnight or those fed a carbohydrate-free diet. 
Two main findings do not support the hypothesis that increased caloric intake is solely responsible for the hyperglycaemia of $o b o b$ and GTG-obese mice. First, while on the high-carbohydrate diet, food intake was comparable in lean and obese mice and yet, blood glucose levels were significantly higher in the obese animal. Second, following overnight fast and when fed a carbohydrate-free diet, obob mice still displayed a mild but significant hyperglycaemia. It can, thus, be argued that the allegedly increased gluconeogenic capacity of the $o b o b$ mice $[15,16,9]$ might be responsible for the hyperglycaemia of these animals when fasted overnight or fed a carbohydrate-free diet. However, under these two conditions the blood glucose was shown to be constant, implying that the rate of glucose entry into the blood stream was equal to that of glucose removal by the tissues. Thus, an increased rate of glucose entry into the blood stream (resulting from increased gluconeogenesis) will lead to normoglycaemia if accompanied by a comparable rise in the rate of glucose disappearance from the blood. If tissues, however, fail to increase the uptake of glucose, the blood glucose will rise until a new steady-state is achieved.

Elucidation of the mechanism involved in the production of hyperglycaemia of the obese-hyperglycaemic mice is provided by the present experiment involving the administration of a trace amount of ${ }^{14} \mathrm{C}$-glucose to mice fed a carbohydrate-free diet. The fractional rate of glucose-loss to the tissues was similar in $o b o b$ mice and lean controls. This, in face of a normal volume of glucose distribution [2] and of a raised blood glucose level in the $o b o b$ mice, suggests a greater absolute rate of glucose uptake by the tissues. Such an increased rate should be expected in these animals due to their expanded body mass. The tissues of the obob mice, however, are capable of maintaining a normal fractional rate of glucose extraction at the expense of a marked increase in serum insulin since, even on a carbohydrate-free diet, there is a 20 -fold increase of circulating immunoreactive insulin concentration ${ }^{2}$.

Thus, on a carbohydrate-free diet (and possibly after an overnight fast) blood glucose and serum insulin levels in the obob mice stabilize at levels allowing an optimal rate of glucose extraction by their expanded adipose tissue. The contrast between glucose-insulin homeostasis in human diabetics and obese-hyperglycaemic mice is obvious, since in the former the absolute glucose uptake by the tissues is normal and the fractional is low $[18,14]$, whereas in the $o b o b$ mice the fractional glucose uptake is maintained at a normal level. Thus, fasting hyperglycaemia in human diabetes is caused by a failure of tissues to maintain a normal fractional rate of glucose uptake, whereas the hyperglycaemia of obesehyperglycaemic mice, subjected to overnight fast or to a carbohydrate-free diet, appears to be a consequence of their expanded adipose tissue, which is also respon-

2 In the present discussion the assumption is made that the insulin of the obob mice is of normal biological activity [19]. sible for their insulin resistance [3]. In both cases the hyperglycaemia represents a compensatory physiological response. Obese-hyperglycaemic mice could become euglycaemic only by increasing the fractional rate of glucose extraction above normal. Such an increase, however, would require a further rise in the already elevated serum insulin levels, and might have the undesirable effect of suppressing the production of endogenous glucose [20]. These data, thus, are consistent with previous observations that hyperglycaemia, hyperinsulinaemia, and insulin resistance in the obesehyperglycaemic mice are secondary to obesity $[2,3]$.

Acknowledgements. This work was supported in part by a Buswell Fellowship from the State University of New York at Buffalo and a Diabetes Training Program NIAMD AM-05507-04. The author is indebted to Mr. David Kolody for his excellent technical assistance.

\section{References}

1. Bray, G.A.: A simple efficient liquid scintillator for counting aqueous solutions in a liquid scintillation counter. Analyt. Biochem. 1, 279-285 (1960).

2. Chlouverakis, C., Dade, E.F., Batt, R.A.L.: Glucose tolerance and time-sequence of adiposity, hyperinsulinaemia and hyperglycaemia in obese-hyperglycaemic mice (obob). Metabolism 19, 687-693 (1970).

3. - White, P.A.: Obesity and insulin resistance in the obese-hyperglycaemic mouse (obob). Metabolism 18, 998-1006 (1969).

4. - Unpublished observations.

5. Coleman, D.L., Hummel, K.P.: The effects of hypothalamic lesions in genetically diabetic mice. Diabetologia 6, 263-267 (1970).

6. Delisle, G., Fritz, I. B.: Interrelations between hepatic fatty acid oxidation and gluconeogenesis: A possible regulatory role of carnitine and palmityltransferase. Proc. Nat. Acad. Sci. 58, 790-797 (1967).

7. Hales, C.N., Randle, P.J.: Immunoassay of insulin with insulin-antibody precipitate. Biochem. J. 88, $137-145$ (1963).

8. - Kennedy, G.C.: Plasma glucose, non-esterified fatty acid and insulin concentrations in hypothalamichyperphagic rats. Biochem. J. 90, 620-624 (1964).

9. Herberg, L., Major, E., Hennings, U., Gruneklee, D., Freytag, G., Gries, F.A.: Differences in the development of the obese-hyperglycaemic syndrome in obob and NZO mice. Diabetologia 6, 292-299 (1970).

10. Katsuki, S., Hirata, Y., Horino, M., Ito, M., Ishimoto, M., Makino, N., Hososako, A.: Obesity and hyperglycaemia induced in mice by gold-thioglucose. Dia. betes 11, 209-215 (1962).

11. Kennedy, G.C., Parker, R.A.: The islets of Langer. hans in rats with hypothalamic obesity. Lancet 1963 II, 981-982.

12. Mayer, J., Bates, M.W., Dickie, M.M.: Hereditary diabetes in genetically obese mice. Science 113, 746$747,(1951)$.

13. cited by Mayer, $J$, in "The physiological basis of obesity and leanness". Nutr. Abst. Rev. 25, 871-883 (1955).

14. Reaven, G.M., Silvers, A., Farquhar, J.W.: Study of the relationship between plasma insulin concentration and efficiency of glucose uptake in normal and mildly diabetic subjects. Diabetes 19, 571-578 (1970). 
15. Sandler, R., Herrera, E., Frienkel, N.: Glucose overproduction in obese-hyperglycaemic mice. Clin. Res. 16, 351 (1968).

16. Seidman, I., Harland, A.A., Teeber, G.W.: Hepatic glycolytic and gluconeogenic enzymes of the obesehyperglycaemic mouse. Biochim. Biophys. Acta 146, $600-603$ (1967).

17. Snedecor, G.W.: Statistical methods. (5th edition) The Iowa State University Press, Iowa: Ames 1956.

18. Soskin, S., Levine, R.: A relationship between the blood sugar level and the rate of sugar utilization, affecting the theories of diabetes. Amer. J. Physiol. $120,761-770$ (1937).

19. Stauffacher, W., Lambert, A.E., Vechio, D., Renold, A.E.: Measurements of insulin activities in pancreas and serum of mice with spontaneous ("Obese" and
"Now Zealand Obese") and induced (gold-thioglucose) obesity and hyperglycaemia with considerations on the pathogenesis of the spontaneous syndrome. Diabetologia 3, 230-237 (1967).

20. Weber, G., Singhai, R.L., Stamm, N.B., Srivastaba, S.R.: Hormonal induction and suppression of liver enzyme biosynthesis. Fed. Proc. 24, 745 (1965).

C. Chlouverakis, M.D.

Research Associate Professor

Department of Medicine

State University of New York at

Buffalo and E.J. Meyer Memorial

Hospital

4.62 Grider Street

Buffalo, New York 14215

USA 